\title{
Good Guest, Bad Guest: The Micro-Geographies of Violence in Urban Kenya
}

\author{
SARAH JENKINS \\ Centre for Trust, Peace and Social Relations, Coventry University, Coventry, UK
}

This article analyses the 2007-08 postelection violence in Kenya arguing that there were significant socio-spatial variations to the conflict in urban areas that can be better understood through an analysis of localised framing processes. It argues that, in some urban neighbourhoods, an underlying frame of autochthony is (re)produced through lived experience, facilitating the casting of ethnic others as either good or bad guests in times of political transition. The flawed elections of 2007 justified the violent eviction of 'bad' guests in these settings. This frame of autochthony, however, is absent in other urban neighbourhoods, and so these spaces remained relatively calm for the duration of the crisis. The article further argues that the flexibility of the good guest/bad guest frame enabled its reconfiguration at the local level, leading to variations in the fault lines of conflict across both time and space. It concludes that frame analysis can help to elucidate these micro-geographies of conflict.

\section{INTRODUCTION}

On 30 December 2007, Kenyans went to the polls for the fourth time since the reintroduction of multiparty politics in 1992. After a heated campaign period, an election day riddled with irregularities, a visible bungling of the counting process and an unexpected victory for the incumbent president, Mwai Kibaki, violence erupted across the country. The conflict raged until a power-sharing agreement was reached at the end of February 2008, leaving approximately 1,300 people dead and over 650,000 displaced..$^{1}$ Kenya's legacy of violent ethnic politics has attracted significant scholarly attention over the years, and there are a number of valuable explanations of the phenomenon. Most of these analyses follow conventional lines of enquiry in ethnic conflict research, focusing upon elite behaviour, mass mobilisation and the structural factors that make conflict more explicable; that is to say, they fall predominantly into the 'why publics follow' and the 'dogs that bark' camps.' ${ }^{2}$ Whilst offering important insights into the causes of ethnic violence in Kenya, many of these analyses struggle to account for local nuances in conflict dynamics and fall short of a locally sensitive understanding of the violence, particularly in the urban arena. In fact, the 2007 - 08 postelection violence was 
marked by significant urban socio-spatial variations that cannot be accounted for by existing explanations alone. Whilst ethnicised urban spaces - that is neighbourhoods and villages dominated by one ethnic group - experienced a sudden descent into intense and acute violence following the announcement of the presidential results, more ethnically mixed areas - non-ethnicised spaces - tended to remain relatively calm for the duration of the crisis. In addition, whilst the violence reflected the politico-ethnic fault lines of the elections in some neighbourhoods, in others, ethnic animosities were reshaped by the local context. This paper explores these urban micro-geographies of the Kenyan crisis, demonstrating that localised framing processes helped shape the micro-level dynamics of conflict. It suggests that narratives of autochthony have emerged in the urban context in Kenya. Autochthony literally means 'sons of the soil' and refers to myths of origin and claims of 'native' status. These discourses are also being (re)produced in everyday life in ethnicised urban spaces, and facilitated the framing of ethnic minorities as either 'good' or 'bad' guests in the 2007 elections. On the other hand, this frame had little resonance in non-ethnicised spaces where autochthonous discourses are less compatible with lived experience. Moreover, the inherent flexibility of the good guest/bad guest frame enabled localised variations in the fault lines of conflict. The paper draws upon an argument articulated in an earlier paper of mine - that the postelection violence can be understood, in part, as a performance of territorialised identity narratives. ${ }^{3}$ However, it moves beyond this analysis by demonstrating not only the variability of these discourses in urban spaces and the socio-spatial dynamics of urban violence, but also by highlighting how the narrative can be used by local-level actors to reframe who constitutes 'the enemy.'

The paper begins by providing a brief summary of the key events leading up to the Kenyan postelection violence before reviewing some of the more prominent analyses of ethnic conflict in the country. The third section moves on to identify the roots of the good guest/bad guest frame and highlights its differential applicability across urban space. The concluding section analyses the micro-geographies of the Kenyan postelection violence, explaining the socio-spatial patterns through an analysis of localised framing processes. Thus, in the Kenyan case, frame analysis enhances our understanding of why violence occurs in some places and not in others, and it helps to explain how the fault lines of conflict can shift over time and space.

\section{THE 2007 KENYAN ELECTIONS}

In the context of Kenya's legacy of violent electoral politics, the relatively peaceful transfer of power in 2002 from the long-standing KANU regime to the newly formed National Rainbow Coalition (NARC), for many, 'heralded expectations that a new political era of democracy had dawned in Kenya. ${ }^{4}$ However, these expectations were soon met with disillusionment and disappointment as the new administration - led by the Kikuyu president, Mwai Kibaki - failed to deliver on many of its campaign promises. High profile corruption scandals, the failure to honour a memorandum of understanding to distribute power evenly amongst NARC factions and the 
'Kikuyuisation' of 'plum' jobs indicated to many that the administration had reverted back to the corrupt and tribal style of the past. However, it was the contentious draft constitution and the subsequent referendum that marked the apex of political fragmentation and sowed the seeds of the ethnic polarisation of 2007.

One of the key campaign platforms of the NARC alliance in 2002 was the ambitious promise of enacting a new constitution within 100 days of assuming power. By 2005, however, when the country finally went to a referendum, the proposed new constitution of Kenya was a significantly watered-down version of the earlier draft and was widely regarded as a betrayal of Kenyan democracy, as a document that served the exclusive interests of Kikuyu hardliners within the government. ${ }^{5}$ An alliance of leading politicians from the Kalenjin, Luo, Luhya, Kamba and Coastal communities - led by Raila Odinga - emerged to contest the proposed constitution and under the Orange Democratic Movement (ODM) banner, they campaigned against the government. ODM were victorious and the constitution was defeated by a significant margin. However, widespread perceptions that the Kikuyu community alone had remained loyal to Kibaki in the referendum reinforced notions of their isolation from other Kenyans. ${ }^{6}$ The rhetoric of 'all-against-the-Kikuyu' emerged and intensified in the lead-up to 2007 as ODM was registered as an official party. Thus, the 2007 elections were to pit Luo, Raila Odinga and his multi-ethnic ODM alliance against Mwai Kibaki's predominantly Kikuyu Party of National Unity (PNU). Anti-Kikuyu sentiment was high by 2007; the campaign period was marked by hate speech on the part of both political elites and ordinary Kenyans, and it was punctuated by incidents of small-scale violence and intimidation.

Given the multi-ethnic nature of ODM, and the fact that the party was seen as an alliance of 41 tribes setting themselves against one, many Kenyans firmly believed that the party could not be defeated if the elections were free and fair. Whilst it was widely perceived that Central Province - the ancestral homeland of the Kikuyu community - would remain loyal to 'their man' Kibaki, ODM was believed to enjoy considerable support in almost all other provinces. According to this ethnic arithmetic, then, Raila Odinga and his ODM party were expected to win the presidential election. So when Kibaki was unexpectedly announced as President, ODM supporters were convinced that the election had been rigged. Taking to the streets in protest, members of ODM-affiliated communities attacked their Kikuyu neighbours almost immediately after the announcement, and as the violence continued some Kikuyu began to launch their own retaliatory attacks. The country descended into spirals of hatred and revenge, coming to an end only when a powersharing agreement was brokered between the two principals under the mediation of Kofi Annan on 28 February 2008.

\section{EXISTING EXPLANATIONS OF ETHNIC VIOLENCE IN KENYA}

Existing explanations of ethnic violence in Kenya have highlighted the centrality of four key factors, namely: the zero-sum nature of neo-patrimonial politics and a context of deliberately weak institutions; elite orchestration and a culture of 
impunity; the diffusion and normalisation of violence; and deep-rooted historical grievances, particularly in relation to land. This section offers a brief overview of these key arguments.

The neo-patrimonial and ethnicised structure of Kenyan politics has turned political competition into a high stakes, winner-takes-all ethnic game in which both elites and local level actors alike are willing to resort to any means to secure victory in the polls. The allocative and coercive capacity of the presidential seat, ${ }^{7}$ in addition to the vast opportunities for personal enrichment attached to it, has ensured that leaders are 'dying to win' and are more than willing to use violence to do so. ${ }^{8}$ Furthermore, historically, members of the President's community have been widely perceived to benefit disproportionately in the allocation of goods and resources at the expense of other groups. Consequently, for ordinary citizens, capturing the state and putting 'our man' in the presidential seat is regarded as the 'only way to eat' ${ }^{\text {' }}$ and fears of marginalisation and exclusion under the rule of another community are pervasive. ${ }^{10}$ This high stakes, zero-sum ethnic game is central to understanding 'the lengths to which leaders and followers are willing to go to get their leader into power. ${ }^{11}$ Moreover, the context of deliberately weak institutions that are controlled and manipulated by the state - where electoral oversight bodies are deeply distrusted, and dispute mechanisms are regarded as biased and partial 'pushed the resolution of Kenya's elections off the table and into the streets. ${ }^{12}$

A second pervasive argument in the literature is that elites 'play the ethnic card'; they manipulate latent ethnic tensions, 'pitting one community against the other', ${ }^{13}$ and they organise, fund and direct violent ethnic militias in pursuit of their political agendas. Several scholars have identified elite fragmentation as a key motivator in this 'instrumentalisation of disorder.' ${ }^{14}$ As political and economic resources dwindled in the 1980s, the system of patronage networks that had sustained a fragile elite alliance began to shrink, breaking up the predominant unity of political leadership. Whilst the elite pact had previously mitigated against the mobilisation of ethnic tensions, ${ }^{15}$ amidst calls for political liberalisation alternative opportunities for power and inclusion opened up and politicians began to mobilise their ethnic constituents in sinister ways to better their political position. Furthermore, the failure to prosecute this deliberate use of violence by elites in the past has embedded a clear culture of impunity in Kenya and ensured that, in 2007, there was little disincentive for politicians to stoke tensions and foster violence in order to disrupt and manipulate the electoral process. ${ }^{16}$

The third key explanatory factor that is frequently highlighted is the diffusion of extra-state violence in Kenyan society, and it is often suggested that this facilitated the eruption, spread and intensity of the violence in $2007-08 .{ }^{17}$ Throughout the 1990s, politicians mobilised violent ethnic militias to intimidate and displace opposition supporters - particularly in the Rift Valley - and it has now become commonplace for politicians across the country to employ armed youths as bodyguards and hired thugs during electoral campaigns. ${ }^{18}$ However, the fact that these groups have never been demobilised and persist outside of electoral periods facilitated their reactivation by politicians in 2007. ${ }^{19}$ Additionally, in response to 
rising insecurity and the limited capacity of the state to provide for or protect its citizens, ethnicised gangs have proliferated in urban areas and other parts of the countryside, acting as shadow states and vigilantes..$^{20}$ In many ways, these groups have only further contributed to the increasing levels of generalised crime and violence in the country. ${ }^{21}$ By 2007, then, the state had clearly lost its monopoly on the use of force and the diffusion of extra-state violence, which meant that widespread chaos could be 'ignited easily, but not controlled. ${ }^{22}$

Finally, many, if not most, analyses of ethnic violence in Kenya have drawn attention to the importance of significant 'horizontal inequalities'23 in Kenyan society and grievances over historical marginalisation, discrimination, exclusion and domination - both real and perceived. In this context of deep-seated grievances violence is understood to ensue when 'one feels compelled to act against the unjustly dominant groups as a way of changing the imbalance', ${ }^{24}$ or out of a desire on the part of the dominant group to maintain its position of hegemony. ${ }^{25}$ Whilst grievances in Kenyan society revolve around a variety of socio-economic and political issues, the land question is frequently identified as the most significant issue that has repeatedly fuelled episodes of violence in the country. The re-Africanisation of land appropriated by European settlers followed 'highly skewed and unequal patterns, ${ }^{26}$ as certain communities were favoured over others. In particular, large tracts of land in the Rift Valley - to which the Kalenjin laid claim - were distributed to other communities in government settlement schemes. The sense of historical injustice over this pattern of land allocation provides significant fuel for politicians to stoke tensions and stir up conflict during elections. More than this, however, it has allowed leaders to use land as a patronage resource, and members of ethnic militias are often promised the land of their victims as a reward for their participation. ${ }^{27}$ As several scholars have noted, it is not insignificant that settlement schemes have been a major loci of violence in the Rift Valley. ${ }^{28}$ Thus, as Cheeseman surmises, 'salient ethnoregional identities reinforced by historical grievances over land ownership, economic inequality and political exclusion, are central to an understanding of the Kenya crisis. ${ }^{29}$

In addition to highlighting these key drivers of conflict, analyses of the 2007-08 post-election have also sought to disaggregate the various forms of violence that constituted the crisis. Three key - and largely overlapping - components of the postelection crisis have been identified: spontaneous, planned and state-driven. ${ }^{30}$ The initial phase of violence was dominated by the spontaneous violence that exploded in response to the flawed elections and that assumed a clear ethnic dimension. Members of Kikuyu communities were attacked in ODM zones across the country, and in some places - most notably Nyanza and Western - these ethnicised attacks were also supplemented by the targeting of government institutions. ${ }^{31}$ This phase of violence was carried out by a range of actors including ordinary citizens, ad hoc criminal gangs, as well as armed groups attached to politicians. ${ }^{32}$ Planned and premeditated forms of violence have been identified as the second key component of the crisis, and most accounts note that this was most prominent in the Rift Valley region as Kalenjin militias were transported and funded 
to carry out attacks against Kikuyu residents. As the violence proceeded a more organised element emerged in other areas of the country as local politicians and business people paid youths to perpetuate the conflict and protect their properties, and larger groups such as the Mungiki, very likely with support from leading politicians, organised retaliatory attacks. ${ }^{33}$ The third form of violence highlighted in the literature is violence perpetrated by state agencies. Many accounts note that the police and other security agencies were responsible for a significant number of casualties and that their involvement was marked by ethnic partiality and an excessive use of force, even in the face of some of the initially more peaceful mass demonstrations that constituted some of the very early stages of the crisis. ${ }^{34}$ Thus, there is a rich literature that highlights the complexity of violence and multiplicity of actors that perpetuated the conflict.

These explanations go a long way in explaining how and why Kenya exploded in 2007 - 08, and in understanding the various dynamics of violence that characterised the crisis across the country. However, there has been little disaggregation of urban violence, and existing accounts fall short of explaining the micro-level dynamics and indeed, the dynamism - of the conflict in this arena. Spatial variations in violence participation cannot be easily explained through an analysis of elite motivations and structural factors alone; some further theoretical tools are needed.

\section{FRAMING AND THE KENYAN POSTELECTION VIOLENCE}

The dominant explanations of ethnic violence in Kenya are often not well equipped to account for micro-level variations in conflict dynamics. Frame analysis can help to address this gap. Since Snow et al.'s discussion of frame resonance, ${ }^{35}$ there has been a tendency for scholars to emphasise the calculated, strategic and intentional communication of frames by actors in pursuit of their goals. ${ }^{36}$ Undoubtedly, this can play into conflict dynamics. However, sole - or even primary - focus upon this dimension obscures the power of socially and culturally embedded frames to shape perception and behaviour on the ground, independent of elite manipulation, and it does not always explain differential resonance across time and space. Frames are socially constructed mental structures that shape the ways in which events are interpreted, perceived and responded to by local level actors; ${ }^{37}$ they are 'organizational premises' that influence action and behaviour, and they must be sustained and maintained through everyday practices and activity. ${ }^{38}$ That is to say, frames are produced and reproduced, and in some cases challenged and reconfigured through everyday life and experience. The relationship of frames to everyday practice means that they are mediated through by local contexts, and consequently are not wholly consistent and uniform across time and space. Indeed, certain frames can hold either more or less relevance to people's everyday lives. This not only affects the success or failure of strategic framing efforts, but it also means that local level actors themselves perceive of and 'frame' events - and the most appropriate response to those events - in different ways. Localised framing processes undoubtedly influence conflict dynamics and should be examined in more depth. 
The subsequent discussion applies frame analysis to the Kenyan postelection violence, focusing primarily upon spontaneous, ethnicised forms of violence that arose in the urban context. It first identifies a host-guest dichotomy as the underlying frame of the conflict and situates this within everyday narratives of autochthony; it then demonstrates how the frame was amplified in the lead-up to the elections and how it shaped conflict dynamics, before concluding with a discussion of the frame's flexibility. Throughout the analysis, I argue that frame analysis can render the urban socio-spatial variations of the Kenyan postelection violence more explicable.

\section{Autochthony and Everyday Ethnicity in Urban Kenya}

Myths of origin are a common feature of ethnic identification around the world, but they are particularly pronounced in the African context where the sense of spatial entitlement is reinforced by the historical relationship between ethnicity, territory and political boundaries. Whilst pre-colonial migration and settlement patterns laid some of the groundwork for attachments to space in Kenya, the colonial demarcation and administration of native reserves and the maintenance of these political boundaries in post-colonial politics has embedded territorialised identity narratives in Kenyan consciousness. ${ }^{39}$ Consequently, an insider/outsider dichotomy has emerged as the various provinces and regions have become universally understood as being the home of particular ethnic groups. Ethnic others living within these provinces are identified as 'immigrants' and 'guests' who can be subjected to a reduced citizenship status in times of political transition or uncertainty. ${ }^{40}$ As one interviewee states, 'You've been welcomed [.. . . here. Keep in mind people, it will cost you to go to someone else's land. I cannot just go to Kakamega. I'll not claim that it is mine. It belongs to someone. ${ }^{41}$ Recent scholarship has drawn attention to a resurgence of similar autochthonous discourses around the world, where selfproclaimed 'sons of the soil' query the citizenship status of 'non-native' communities and seek to impose significant constraints upon 'migrants' living in the area. ${ }^{42}$ In Kenya, these constraints are almost always related to issues of resource distribution and the control of the political and economic spheres. 'Immigrant' dominance of land, business, property, employment opportunities and other positions of economic privilege generates significant resentment amongst 'host' communities. As one interviewee explains, 'Say like you are from Manchester and I am from Liverpool. I come to stay in Manchester, but I come there and I get privileges. How will you feel? [Or say] I'm from Eldoret, I was born there, but some Kikuyu has the land. How will it happen? ${ }^{43}$ Intimately related to this issue of economic dominance is the belief that the native community should have more political say in their territory and that minority groups should not oppose the leanings of the host community. ${ }^{44}$ That is to say, minorities are expected to acquiesce to the political wishes of the majority: 'When you go to Rome you do what Romans do ... if you are going to stay here you must do what the people here want. ${ }^{45}$ Thus, autochthons expect to be favoured in the distribution of economic resources in their own areas, and resent any appearance of non-native dominance - or attempts at dominance - of the political arena. 
What is perhaps less frequently acknowledged, however, is that these autochthonous discourses are being reproduced in urban areas. In the informal settlements of Kenya's cities, as neighbourhoods and villages come to be dominated by particular communities through rural-urban migration patterns, narratives of belonging and ownership emerge. As a Kamba youth living in Mathare slum explains:

In this area the villages are along a tribal line. Some of the villages the majority are Kambas, like Viet there by Moi Air Base, and it borders the Luo area [.. .] Then there is a place belonging to Kikuyu, every tribe has their village. $^{46}$

Just as autochthons in rural areas expect to be favoured over 'immigrants', similar expectations of preference and superiority are apparent amongst majority communities in urban neighbourhoods. Perceptions of relative disadvantage vis-àvis other ethnic groups in the area can foster resentment and a sense of injustice. For example, a number of interviewees in Kibera point out that whilst the Luo constitute the majority, and the slum is understood by many to be 'Luo territory, ${ }^{47}$ very few Luos own their houses. Instead, most are tenants of either Kikuyu or Nubian landlords and this is a significant source of tension. One resident stated, 'when they see that they are the majority here they think that they can rule. They are so many here but they don't have houses here. The problem came from that side.' ${ }^{48}$ Similarly, a Luo youth from Mathare expressed his discontent that members of his community were living in extremely poor conditions, despite the fact that they 'owned' the space. He exclaims, 'See how this house is? You're in your own area, but you live like this and you're in your own area?!' ${ }^{49}$ Moreover, just as 'immigrants' are subject to political expectations and constraints at the regional level, urban minorities are also expected to vote with the host community: 'If you don't vote for our people, you can't live here. ${ }^{50}$

The instability of autochthonous claims has been emphasised by a number of scholars both in the Kenyan case and across the African continent more generally. Claims of indigeneity and belonging are frequently challenged by those who arrived second, ${ }^{51}$ and 'the idea of belonging "more" than others' has become a common feature of autochthonous narratives. ${ }^{52}$ This is particularly true in the Kenyan case, where few communities can claim to be 'deep-rooted sons of the soil' 53 and where multiple and overlapping identity boundaries create additional dimensions of complexity in claims of belonging. ${ }^{54}$ Lonsdale has suggested that in this context, autochthonous claims can be based upon three idioms: understanding the land which is the prerogative of first-comers; controlling the land - through pastoral expertise, for example; or working the land as farmers and making it more productive. ${ }^{55}$ Urban areas constitute an even more unstable arena for the politics of belonging to play out, and everyday practice becomes all the more important in producing, maintaining and challenging 'imagined geographies. ${ }^{56}$ Indeed, it is the dominance of territory that appears to be the strongest claim to 'autochthony' in urban contexts, ${ }^{57}$ and this is often asserted through a visible ethnicisation of space. 
The numerical superiority of particular communities and the construction of an insider/outsider framework becomes highly visible in everyday expressions of ethnic identity - both in the "banal' ${ }^{58}$ indicators that are 'such a familiar part of the social environment that they operate mindlessly, rather than mindfully, ${ }^{59}$ and in the more demonstrative performances of cultural identity. Banal expressions of ethnicity exist in abundance and are often so subtle that they pass by largely unnoticed. The visual and audible cues that Kenyans draw on to ascribe ethnic identity, for example - such as physical stature, accent, conversational style, behavioural characteristics - highlight ethnic predominance in an area and serve as an indicator of who belongs and who does not. Similarly, signposts advertising vernacular church services, or billboards advertising the sale of ethnic dishes reaffirm the sense of ethnic ownership, and the more demonstrative performances of identity that occur during life-cycle events - such as weddings, funerals, and other cultural celebrations - further contribute to the ethnicisation of urban space. Perhaps, the clearest indicator of ethnic predominance is the use of language. It is not uncommon to hear vernacular languages spoken in ethnicised urban settings. In 4B, Mathare, two interviewees were unable to converse in Sheng (a slang language of the youth), Kiswahili or English, and we had to carry out the interview in their mother tongue, suggesting that the Jaluo language is used extensively in the area. Even when Sheng is the principal language of communication, it is commonly inflected with vocabulary from the dominant community's mother tongue. As Mazrui notes, 'There are local variations of the language which betray the presence of ethnically predominant groups in the respective localities. ${ }^{90}$ Thus, through these banal and demonstrative acts, urban spaces become visibly ethnicised, and as one interviewee states, there is a sense that 'all you need to do is go around in their neighbourhoods and you can see the difference. ${ }^{\prime 61}$

The spatial concentration of ethnic communities should not be understood as 'a residential agglomeration of social groups in neutral and static space'; ${ }^{62}$ rather, these everyday expressions of ethnic identity act as a symbolic appropriation of space, and serve to construct insider/outsider, host/guest dichotomies. Indeed, numerical supremacy is conflated with narratives of ownership and belonging, and in some cases the name of a neighbourhood is even altered by residents to reflect this. For example, in Eldoret and Nairobi Luo-dominated villages have been renamed Kisumu Ndogo, meaning 'Little Kisumu' - Kisumu being the capital of the Luo province of Nyanza. ${ }^{63}$ Thus, in urban areas, the underlying frame of autochthony is produced and maintained through the continual 'flagging' ${ }^{64}$ of ethnic predominance and the everyday signs of spatial ethnicisation.

In contrast, however, there are a few non-ethnicised territories within Kenya's urban slums, where there is no clear majority community. Banal indicators of identity reflect the more ethnically mixed demography of the area and more demonstrative performances of ethnicity are infrequent within these spaces. Thus, lived experience fails to generate the sense of ethnicised belonging, entitlement and exclusion found elsewhere. A resident of Nigeria, Mathare, for example asserts, 'All the communities live here, no community dominates. In those other places 
down there, either the Kikuyu or the Luo dominate but here every tribe lives here. ${ }^{65}$ Similarly, in Kenya Service, a village on the outskirts of Eldoret, residents emphasised the cosmopolitan nature of the area. As one interviewee states, 'All the tribes are here [.. .] But there [in the neighbouring villages] everyone is in his place. ${ }^{\prime 66}$ Thus, the underlying frame of autochthony is absent from these urban neighbourhoods. No community is recognised as having a greater right to the economic resources of the area nor are residents expected to vote in a particular way. The autochthonous frame is challenged by everyday practices of interaction and inclusion.

Recognising these everyday constructions of ethnically inclusive or exclusive urban spaces is crucial to understanding the socio-spatial patterns of the $2007-08$ postelection violence. It is this frame of autochthony that was amplified during the election period and which underscored the conflict. Consequently, where everyday practices of identity challenge the notion of ethno-spatial belonging, the frame failed to resonate and flourish.

\section{Punishing 'bad' guests in the 2007 elections}

In the lead-up to the 2007 elections, and throughout the course of the violence, the autochthony frame was amplified both strategically by political elites and more organically at the local level. Notions of spatial ownership and entitlement were vocalised and actively performed during the campaigns as minorities were reminded - sometimes violently - of their secondary citizenship status, particularly in regard to political behaviour. Furthermore, much of the conflict itself was shaped by the desire to punish and evict 'bad' guests who had betrayed the majority community in the elections rather than by any attempt to exterminate or kill off one ethnic group. ${ }^{67}$ However, as Benford and Snow note, this process of frame amplification involves invigorating and highlighting already existing interpretative frames, ${ }^{68}$ and so, whilst the host/guest discourse came to the fore in ethnicised settings, it could not flourish or resonate in non-ethnicised spaces where autochthony is not embedded in lived experience. Thus, whilst ethnic spaces were marked by substantial tension and conflict during the campaigns and descended into acute violence immediately after the presidential announcement, non-ethnicised territories remained calm throughout the crisis.

During the campaigns, in addition to propagating derogatory and hateful language about other communities, political elites also played upon territorialised identity narratives and expectations of spatial politico-economic dominance in an effort to mobilise their followers and intimidate opposition supporters. This was particularly pronounced at the macro-regional level, where politicians were able to tap into these narratives through the discourse of majimbo (devolution). This federalist system of government became a key platform of the ODM campaign, offering communities the potential for greater power and inclusion in the political and economic spheres and an assurance of protection against marginalisation. However, majimbo also resonated as a more sinister proposal for the homogenisation of ancestral homelands and the 'repatriation' of 'foreigners', playing directly into local desires for exclusive 
political, economic and social control of their own territories. Indeed, ODM politicians were deliberately vague in their elucidation of majimbo in order to facilitate the spread of this more negative interpretation. ${ }^{69}$ In addition to this more passive means of amplifying the host/guest frame, a number of national and local level politicians made more direct reference to notions of removing 'foreigners' from native territory. In the Rift Valley, for instance, the phrase 'kuondoa madoadoa' 'remove the stains or dots' - was used regularly during the campaign period, and several interviewees reported that elites promised to return the land to its 'rightful owners' upon their election. Thus, political elites amplified the frame of autochthony by highlighting the non-native status of ethnic others, by invigorating notions of rightful ownership of land and other economic resources, and by fostering the negative interpretation of the majimbo rhetoric. Local-level politicians also accentuated notions of territorial ownership in urban spaces and fears of minority domination. In Mathare, for example, ODM politicians reportedly played upon resentments over Kikuyu dominance in the area, stating, 'You people are like underdogs living on less than a dollar a day. Why is everything here for the Kikuyus?'70

Whilst these top-down efforts to accentuate autochthonous discourses certainly resonated in ethnicised settings, local, bottom-up amplification processes were far more pervasive and indeed explicit, in invigorating the good guest/bad guest frame. The borders between ethnic territories became increasingly reified in the lead-up to the elections as residents made the political preference of the area apparent. Ethnicised neighbourhoods became "no-go zones" ${ }^{11}$ for any form of alternative politics. The campaign posters of the majority community's party were pasted around the territory, and indeed were the only campaign materials permitted in the area. Campaigners caught trying to erect posters for the 'wrong' party were often attacked and chased from the area. Similarly, anyone passing through the village wearing the t-shirt of an unacceptable party would be abused or beaten - and, on occasion, even killed - as residents policed the politics of the space. Candidates from other parties were violently prevented from entering ethnic enclaves, and any opposition rallies that did penetrate the borders were soon disrupted by youths of the area. In some places, residents even scrawled the letters ODM or PNU on the structures of the slum and on the roadways visibly politicising the territory and asserting the rules of hospitality to which 'guests' were expected to abide. One interviewee explained that during the campaigns "you must respect the borders' ${ }^{72}$ and another surmises:

This area is an ODM zone. If you come here and you shout "PNU!" you are calling for death for yourself and if you go there to PNU areas and shout "ODM!" you'll be in shit. You have to go with the chorus of the area, if it is ODM and you're PNU, you just follow the chorus. ${ }^{73}$

In this suffocating political environment, expectations of conformity were clear and facilitated the casting of ethnic others as either good or bad guests. Those who were thought to be opposing the majority community's wishes were framed as 'bad' 
guests who needed to be reminded of their secondary citizenship status; they were intimidated and threatened throughout the campaign period, and were explicitly warned that if they were to vote against the wishes of the host community, they would no longer be welcome to stay in the area: 'if you don't vote for us, you must leave our area. ${ }^{74}$ One Kikuyu interviewee's recollection of an incident during the campaign period is particularly revealing of the accentuated articulation of the guest frame. As an electrician from Huruma in Eldoret, he had travelled to a neighbouring Kalenjin village for work. Having completed the job, his client refused to pay him, telling him:

"My friend, if you come to me and you see me eating meat, then you must also eat meat [.. .] You don't eat greens, because I am eating meat." [.. .] He was telling me that you must do what you get me doing. It was because I am not one of them, so the meaning is that here in Eldoret we are like visitors and we must do what the owners do. If it is to vote for Ruto, then we must vote for Ruto and not to vote for someone else. That is what he was telling me. That man didn't pay me. ${ }^{75}$

Notice here that not only are the political expectations of conformity clearly vocalised, but control of the economic realm is also alluded to, as the Kalenjin client refuses to pay a 'bad' guest who is not respecting the rules of hospitality.

By contrast, however, those perceived to be, or visibly seen to be, supporting the right party were framed as 'good' guests who were welcome to engage in politics in the area. ${ }^{76}$ Consequently, on the ODM side, entire communities - such as the Luhya, the Kalenjin, the Luo, and the Kamba - were cast as 'good' guests in ODM zones, as they were perceived to be part of the ODM alliance. More revealingly, however, is the fact that Kikuyu candidates running on ODM tickets in ODM areas enjoyed significant support in ODM-affiliated enclaves, as they were seen to be operating within the parameters of acceptability. In Kawangware, a Kikuyu youth known as KJ mobilised significant support in the Luo and Luhya dominated territories of 56 and Satellite, and similarly a Kikuyu civic candidate was able to run his campaign in Kibera without threat or intimidation. Similarly, ordinary residents who were seen to be active supporters of the 'right' party were also privy to good guest status. A Luo youth who worked in Kikuyu-dominated Shabab, Nakuru, for example, explained that 'the Kikuyu are the majority here, so I was on the PNU side ${ }^{77}$ and he was well accepted in the area. Similarly, in Gatuikera, Kibera a Kikuyu youth escaped the intimidation and threats other residents reported being subjected to because he was an active supporter of ODM. Indeed, some residents made a conscious effort to be vocal in their support of a particular party in order to demonstrate clearly their acquiescence to the rules of hospitality - even if, at times, this conformity was largely pretence. In Kibera, for example, one Kikuyu youth explained that he was attacked on two occasions for his heavy involvement with the PNU campaign. He subsequently pretended to switch his support to ODM in order to prevent attacks and to be seen as an acceptable political presence in the area: 
The second time I was attacked it was during night hours. [.. .] We changed our PNU t-shirts for ODM ... [They said] 'Hey I know you, I thought you were for PNU?' I said, 'No, brother, we are ODM now,' so I called this guy [he points to his friend ] and I tell him, 'We must do something. There is a rally tomorrow for Raila. We must join with those guys so that they can see we are for ODM.' They are then saying 'Ah, he is with us for ODM now' and I say, 'Yes, I have changed. ${ }^{78}$

Thus, members of minority communities who adhered to the political rules of hospitality - or who at least appeared to do so - were largely accepted in the area and cast as good guests.

Following the announcement of the presidential results and the outbreak of violence, the good guest/bad guest frame further defined the nature of the violence in urban areas. Rather than being an effort to kill off a particular community, the violence was framed by an attempt to punish and evict bad guests. As one interviewee recalls, his attackers told him: 'This is an ODM zone and you chose PNU so you must suffer the consequences. ${ }^{79}$ Minorities who were perceived to have voted against the wishes of the host community were chased away from the area, their houses were burned and their businesses razed to the ground to prevent them from returning to the area. The tendency to either burn or, in some places to appropriate, minority's businesses further illustrates the underlying frame of autochthony, majority communities sought to reclaim control of the economic sphere within their territories by removing the minority's means of extraction. As one interviewee concedes, 'We thought, let us beat up Kikuyu for them to run away to leave for us their businesses. ${ }^{80}$

Important to note, however, is that, at least in the initial phases of violence, members of minority communities who had been seen to be supporting the right party during the campaigns were not targeted. For example, a Luo youth recalled that in Kaptembwa, Nakuru, 'the residents of the area used to say, "Don't break so and so, he was ODM." ${ }^{81}$ Similarly, residents of Ronda, Nakuru, intervened in an attack upon a Kamba resident by Kalenjin warriors from outside the area, exclaiming, 'No, no, don't hurt him. He's a strong ODM supporter, he campaigned with us as a driver. ${ }^{92}$ Thus, members of minority communities who were identified as good guests, as having respected the political wishes of the community were not targeted in the early stages of the violence, and, in some cases, were even protected from attack by others. As the violence progressed, however, even these individuals tended to flee as violence itself came to shift the criteria for good guest status. This dynamic element of conflict is discussed in more depth in the subsequent section.

In contrast, non-ethnicised territories remained relatively calm throughout the campaign period and did not descend into violence following the announcement of the presidential results. The good guest/bad guest frame had little resonance in these spaces, so any rhetoric employed by elites fell on deaf ears, and the frame could not flourish through more locally initiated practices. Indeed, whilst political debate was stifled in ethnicised spaces, and the expectation of political conformity was visibly 
and violently enacted, ethnically mixed spaces enjoyed far greater freedom of political expression. Campaign rallies from both parties were able to operate in these areas since there was no sense of political entitlement in the space. As one interviewee from Nigeria, Mathare, states, 'There were ODM and PNU supporters, the rallies were held here, but there was no hatred. You have a right to campaign here or to campaign anywhere. ${ }^{83} \mathrm{He}$ later notes that, in contrast to ethnicised settings, 'here we're neutral, you can just vote for who you want. No group would come and force you to vote for them. ${ }^{84}$ Certainly, there were arguments and disputes in these areas as people voting for different parties expressed their opinions, but, in the absence of a dominant community with claims of ownership over the territory, the expectation of political conformity was neither present nor policed. Following the announcement of the presidential results, these spaces resisted degeneration into violence, despite the conflict raging in neighbouring villages. Indeed, in the absence of a host- guest dichotomy, residents in these spaces tended to unite to protect their neighbourhoods. As one interviewee in Kenya Service recalls: 'Here our elders in this community called everyone and told us, "You are not a Luo, or a Nandi, or a Kikuyu anymore. We are Kenyans. We must come together to take care of our community." " ${ }^{85}$ Similarly, Nigeria in Mathare did not erupt into violence and was not targeted by the groups fighting in the neighbouring villages. As one Kikuyu woman stated:

Outside this area war was taking place but here things were cool [.. .] In this area it is mixed with all tribes, but in Number 10 and Bondeni the majority are one tribe and the minority are the Kikuyu so they were chased. But here there is no majority and no minority. ${ }^{86}$

Thus, in non-ethnicised settings, no one community lays claim to the space. The host- guest frame is absent from everyday life, and consequently could not be amplified by either political elites or local level actors. As a result, these territories were marked more by cooperation than by conflict, they did not erupt into violent ethnic conflict following the elections, and they were seldom targeted by outside groups.

\section{Casting 'good' and 'bad' guests: the flexibility of the autochthony frame}

The previous section has demonstrated that the autochthony frame shaped both the micro-geographies of the crisis and the nature of violence. In addition to this influence, the inherent flexibility of the frame ensured its amenability to local contexts, to the shifting fault lines of conflict and to the dynamism of violence. Indeed, the classification of good guests and bad guests was not consistent across either time or space. Communities who were bitterly fighting in one area were elsewhere united against a common enemy, and, as the violence continued, previously acceptable communities could be transformed into unwelcome occupiers as the criteria for good guest status changed. 
In the lead-up to the 2007 elections, the 41-against-1 narrative came to dominate the political scene. Consequently, throughout the campaigns, the Kikuyu were cast in the role of 'bad' guests in ODM zones, whilst ODM-affiliated communities living in Kikuyu areas were similarly threatened and intimidated. As such, the framing of who constituted a 'good' or a 'bad' guest was relatively static and uniform across ethnicised spaces. However, the fault lines of the conflict were far less consistent once violence erupted, and there were significant localised reclassifications of good and bad guests. Local demographics, for example, were often crucial to the formulation of good guest/bad guest statuses, and in places where there was a greater threat from external attack by a third community, residents tended to unite to protect their village. In the Kikuyu-dominated centres of Huruma and Munyaka in Eldoret, for example, the tensions throughout the campaigns reflected the macro-political divide, and it was clear to residents that 'this area is for PNU supporters. ${ }^{87}$ However, once the violence had erupted, large groups of Kalenjin warriors launched attacks on the villages and residents from across the ethno-political divide - from the Luo, Luhya and Kikuyu communities - recognised the need to unite against a common Kalenjin aggressor. As one interviewee states, 'at the time of problem you must fight those coming to attack so they [the youth of the area] put politics aside. ${ }^{88}$ Thus, localised contexts required subtle reformulations of the 41-against-1 narrative, and the flexibility of the good guest/bad guest frame facilitated these localised negotiations.

In addition to these spatially contingent constructions of ethnic others, there were also significant temporal shifts in the criteria for good guest/bad guest status. As the violence continued, individuals, and in some cases entire communities, who had initially been regarded as accepted guests found themselves recast as unwelcome occupiers. For example, in the ODM neighbourhoods of Mathare, members of the Kamba community were not initial targets of attack. The party of Kamba politician Kalonzo Musyoka, ODM-Kenya, did not present any significant challenge to Raila's campaign, and the other leading Kamba politician, Charity Ngilu, was a key figure in the ODM alliance. Consequently, the Kamba were cast as acceptable guests. However, on 8 January 2008, with the country engulfed in chaos and the political dispute remaining unresolved, Musyoka accepted the position of Vice President in Kibaki's administration. He was immediately labelled as a traitor by ODM-affiliated communities and members of his Kamba community were recast as bad guests who were no longer welcome to live in ODM zones. As one interviewee noted, 'The Kamba, they were beaten by the Luos because Kalonzo joined Kibaki so the Luos were furious. ${ }^{89}$ He goes on to emphasise the mentality underpinning these shifts: 'If they couldn't support us, then they were our enemies. They had to side with us. ${ }^{90}$ Thus, any sign that a community was acting against the host group could engender a change in their status. In a similar way, the violence itself served to alter relations at the local level. As has been highlighted above, members of minority communities who had been active supporters of the 'right' party during the campaigns were initially protected by local residents. However, as the violence progressed, tensions began to emerge as residents questioned the acceptability of communities 
who were attacking their ethnic kin in other parts of the country. As one interviewee exclaims, 'my people were killed in your area so why should I stay with you here?'91

Local level incidents could provoke similar transformations of good guest/bad

guest statuses. A particularly prominent example was related by a number of

interviewees in Langas, Eldoret. Here, residents suggested that the Kisii were initially on the side of the ODM-affiliated communities in the area stating that after the announcement they joined in with attacks against the Kikuyu. However, when a Kalenjin MP, David Too, was killed by a Kisii policeman, 'it affected the estate, so it brought a problem to the Kisii. The Nandi's were saying, "You have to move.",92 Again, the host- guest frame shaped the violence, and as communities were seen to cross new lines of acceptability during the violence itself, they were recast as bad and unwelcome guests who needed to be evicted from the area. Indeed, this is the inherent danger of the host-guest narrative: hosts get to decide on the rules of the visit, ${ }^{93}$ and these rules can change very quickly.

In sum, conflict is marked by dynamism and variation. An analysis of localised framing processes can help explain the ways in which localised complexities are negotiated and integrated into broader conflict dynamics. The most successful frames - those that will resonate and flourish across a wide range of settings - are those that are flexible enough to be reconfigured to suit local circumstances. In Kenya, autochthonous discourses serve to cast all minority communities as guests who are subject to certain rules of hospitality. However, the rules of hospitality are determined at the local level and they can shift significantly over time and space, transforming acceptable communities into bad guests who are no longer welcome to stay in the area.

\section{CONCLUSION}

Existing analyses of the Kenyan crisis offer valuable explanations of the violence and provide important insights into the structural roots of conflict. However, they often fail to capture the micro-level socio-spatial variations in conflict dynamics, especially in the urban arena. Frame analysis can help to fill this gap in our understanding. This paper has argued that the frame of autochthony underscored the spontaneous, ethnicised forms of urban violence in the 2007 - 08 postelection violence in Kenya and can help to explain how isolated pockets of peace persisted in the informal slums of Kenya's cities. In ethnicised neighbourhoods, the autochthony frame is produced and maintained through banal and demonstrative performances of identity within space. In the lead-up to the 2007 elections, this frame was amplified both by political elites and by local level actors, as the host- guest dichotomy was highlighted and expectations of political conformity were visibly articulated. Those perceived to be compliant to the demands of the host community were cast as good guests, whilst others were branded as 'bad' guests. After the announcement of the presidential results, violence erupted in ethnicised spaces across the country and communities sought to punish and evict guests who had abused the rules of hospitality. However, in non-ethnicised territories, the autochthonous frame is 
absent from everyday life and no host- guest dichotomy exists. Consequently, amplification processes failed to resonate or flourish in these areas, and they resisted degeneration into violence. Finally, the classification of good and bad guests was neither spatially nor temporally consistent, but rather was subject to localised framing processes. Thus, the application of framing to the analysis of the Kenyan crisis draws attention to local level agency during conflict, accounts for variations in violence dynamics across time and space and elucidates the localised processes of violence.

\section{ACKNOWLEDGEMENTS}

The author would like to thank the two anonymous reviewers for their insightful comments on an earlier version of this article. Any errors that remain are, of course, the responsibility of the author.

\section{NOTES ON CONTRIBUTOR}

Sarah Jenkins is a Research Associate at the Centre for Trust, Peace and Social Relations at Coventry University. Her research focuses on the micro-level dynamics of violence and peace, electoral violence, and urban identity and security in subSaharan Africa. Email: sarah.jenkins@coventry.ac.uk

\section{NOTES}

1. Human Rights Watch, High Stakes: Political Violence and the 2013 Elections in Kenya (Human Rights Watch Report 2013) p.1. A Kenya National Commission on Human Rights and the United Nations High Commissioner for Refugees (KNHCR) report estimates that 663.921 persons were displaced in the postelection violence [see KNCHR, Homeless at Home: A human Rights Assessment of Situation of Internally Displaced People in Kenya (Nairobi, December 2011)]. Some scholars, however, have suggested that the figure might be closer to 700,000 (Gabrielle Lynch, 'Durable Solution, Help or Hindrance? The failings and unintended implications of relief and recovery efforts for Kenya's post-election IDPs', Review of African Political Economy 32/122 (2009) pp.604- 10, p.604.

2. Marie-Eve Desrosiers, 'Puzzles and Frames in the Study of Identity-Based Conflict: An Assessment of Framing Theory', this volume.

3. Sarah Jenkins, 'Ethnicity, Violence and the Immigrant-Guest Metaphor in Kenya', African Affairs 445/111 (2012) pp.576-96.

4. Sharack Wanjala Nasong'o and Godwin R. Murunga, 'Prospects for Democracy in Kenya', in Godwin R. Murunga and Shadrack W. Nasong'o (eds.) Kenya: The Struggle for Democracy (Dakar: Zed Books 2007) p.9.

5. Preston Chitere, Ludeki Chweya, Japhet Masya, Arne Tostensen and Kamotho Waiganjo, Kenya Constitutional Documents: A Comparative Analysis (CMI Report 2006) p.50.

6. It should be emphasised here that whilst perceptions of Kikuyu isolation were high, the 2005 referendum did not actually evidence such a clear division. Indeed, some Kikuyu voted against the draft, whilst other non-Kikuyu communities voted in support of it.

7. See for example, Jacqueline M. Klopp, "Ethnic Clashes" and Winning Elections: The Case of Kenya's Electoral Despotism', Canadian Journal of African Studies 35/3 (2001) p.476.

8. Susanne D. Mueller, 'Dying to Win: Elections, Political Violence, and Institutional Decay in Kenya', Journal of Contemporary African Studies 29/1 (2011) p.100.

9. Michael Cowen and Karuti Kanyinga, 'The 1997 Elections in Kenya: The Politics of Community and Locality' in Michael Cohen and Liisa Laakso (eds) Multi-Party Elections in Africa (Oxford: James Currey 2002) p.170. 
10. Susanne D. Mueller, 'The Political Economy of Kenya's Crisis', Journal of Eastern African Studies $2 / 2(2008)$ p.201.

11. Mueller (note 10) p.200.

12. Ibid. p.199.

13. Johan de Smedt, “No Raila, No Peace!" Big Man Politics and Election Violence at the Kibera Grassroots', African Affairs 108/433 (2009) p.584.

14. The 'instrumentalisation of disorder' is a phrase first employed by Patrick Chabal and Jean-Pascal Daloz, in Africa Works: Disorder as Political Instrument (Oxford: James Currey 1999). For texts that examine elite fragmentation as a driver of ethnic violence in Kenya, see Mueller (note 10) p.199; Daniel Branch and Nic Cheeseman, 'Democratization, Sequencing and State Failure in Africa: Lessons from Kenya', African Affairs 108/430 (2008) pp.1 - 26; Peter Kagwanja and Roger Southall, 'Introduction: Kenya - A Democracy in Retreat? Journal of Contemporary African Studies 27/3 (2009) pp.259 - 77; de Smedt (note 13) pp.583-6.

15. Branch and Cheeseman (note 14) p.7.

16. CIPEV, The Commission of Inquiry on Post Election Violence (Nairobi: Government Printer 2008) p.22; Kenya National Commission on Human Rights (KNCHR) On the Brink of the Precipice: A human Rights Account of Kenya's Post-2007 Election Violence (Nairobi, 2008) pp.24 - 5.

17. Mueller (note 10); David Anderson and Emma Lochery, 'Violence and Exodus in Kenya's Rift Valley, 2008: Predictable and Preventable?' Journal of Eastern African Studies 2/2 (2008) pp.328 - 43, p.338; Peter Kagwanja, 'Courting Genocide: Populism, Ethno-Nationalism and the Informalisation of Violence in Kenya's 2008 Post-Election Crisis', Journal of Contemporary African Studies 27/3 (2009) pp.365- 87; Nic Cheeseman, 'The Kenyan Elections of 2007: An introduction', Journal of Eastern African Studies 2/2 (2008) pp.166- 84.

18. de Smedt (note 13) p.595.

19. CIPEV (note 16) p.viii.

20. Mueller (note 10) p.192.

21. Ibid. p.194.

22. Ibid. p.186.

23. Frances Stewart, 'Horizontal Inequalities: A Neglected Dimension of Development', Queen Elizabeth House Working Paper Series, 81 (Oxford 2002).

24. Roger D. Petersen, Understanding Ethnic Violence: Fear, Hatred, and Resentment in TwentiethCentury Eastern Europe (Cambridge: Cambridge University Press 2002) p.263.

25. Stewart (note 7) p.3.

26. Kagwanja and Southall (note 14) p.268.

27. Catherine Boone, 'Politically Allocated Land Rights and the Geography of Electoral Violence: The Case of Kenya in the 1990s', Comparative Political Studies 44/10 (2011) pp.1311 - 42, p.1327.

28. Boone (note 27); Anderson and Lochery (note 17) p.333.

29. Nic Cheeseman (note 17) p.167.

30. Kagwanja and Southall (note 14) p.271; Michael Chege, 'Kenya: Back from the Brink?', Journal of Democracy 19/4 (2008) pp.125 - 40; Godwin R. Murunga, 'Spontaneous or Premeditated? PostElection Violence in Kenya', Discussion Paper 57, Nordiska Afrikainstitutet (2011); Jacqueline Klopp and Prisca Kamungi, 'Violence and Elections: Will Kenya Collapse?' World Policy Journal 24 (2007/08) pp.11 - 8; Government of Kenya (note 16).

31. CIPEV (note 16) p.347.

32. de Smedt (note 13) p.590; Chege (note 30) p.137; for emphasis on gangs attached to politicians see Klopp and Kamungi (note 30) p.12.

33. CIPEV (note 16) p.347.

34. Kenya National Commission on Human Rights (note 16) p.131; CIPEV (note 16) p.417.

35. David A. Snow, E. Burke Rochford, Jr., Steven K. Worden and Robert D. Benford, 'Frame Alignment Processes, Micromobilization and Movement Participation', American Sociological Review 51/4 (1986) pp.464-81.

36. Pamela E. Oliver and Hank Johnston, 'What a Good Idea! Ideology and Frames in Social Movement Theory', Mobilization: An International Journal 5/1 (2000) p.41.

37. George Lakoff, Don't Think of an Elephant! Know Your Values and Frame the Debate (White River Junction: Chelsea Green 2004) p.xv.

38. Erving Goffman, Frame Analysis (New York: Doubleday 1974) p.247.

39. Gabrielle Lynch, I Say to You: Ethnic Politics and the Kalenjin in Kenya (Chicago: University of Chicago Press 2011) p.17. 
40. Jenkins (note 3) p.577.

41. Interview with Nubian woman, Karanja, Kibera, 10 December 2009.

42. For example, Peter Geschiere, The Perils of Belonging: Autochthony, Citizenship and Exclusion in Africa and Europe (Chicago: University of Chicago Press 2009).

43. Interview with middle-aged Nubian man, Makina, Kibera, 16 December 2009.

44. Jenkins (note 3) p.577.

45. Interview with Luhya youth, Langas, Eldoret 15 January 2010.

46. Interview with Kamba youth, Nigeria, Mathare, 18 May 2010.

47. Interview with Luo youth, Olympic, Kibera, 12 December 2009.

48. Interview with middle-aged Kikuyu man, Bombolulu, Kibera, 17 December 2009.

49. Interview with Luo youth, Muradi, Mathare, 2 May 2010.

50. Interview with Luo youth, Satellite, Kawangware, 18 January 2010.

51. Stephen Jackson, 'Sons of Which Soil? The Language and Politics of Autochthony in Eastern D.R. Congo', African Studies Review 49/2 (2006) pp.95 - 123, p.113.

52. Gabrielle Lynch, 'The Wars of Who Belongs Where: The Unstable Politics of Autochthony on Kenya's Mt Elgon', Ethnopolitics 10/3-4 (2011) pp.391-410, p.407.

53. John Lonsdale, 'Soil, Work and Citizenship in Kenya', Journal of Eastern African Studies 2/2 (2008) pp.305-14, p.306.

54. Lynch (note 52).

55. Lonsdale (note 53) p.306.

56. Edward Said, Orientalism (New York: Penguin 2003 [1978]) p.54.

57. Jenkins (note 3) p.593.

58. This concept has been taken from Michael Billig's 'banal' nationalism in Michael Billig, Banal Nationalism (London: Sage 1995).

59. Ibid p.60.

60. Alamin M. Mazrui, 'Slang and Code-Switching: The Case of Sheng in Kenya, Afrikanistische Arbeitspapiere 42 (1995) p.169.

61. Interview with Nubian youth, Karanja, Kibera, 13 December 2009.

62. Izhak Schell and Benjamini Yoav, 'The Sociospatial Isolation of Agents in Everyday Life Spaces as an Aspect of Segregation', Annals of the Association of American Geographers 91/4 (2001) p.622.

63. Jenkins (note 3) p.582.

64. Billig (note 58) p.8.

65. Interview with Somali youth, Nigeria, Mathare, 20 May 2010.

66. Interview with young Borana woman, Kenya Service, 11 February 2010.

67. Jenkins (note 3) p.590.

68. Snow et al. (note 15) p.469.

69. David M. Anderson, 'Majimboism: The Troubled History of an Idea' in Daniel Branch, Nic Cheeseman and Leigh Gardner (eds.) Our Turn to Eat: Politics in Kenya since 1950 (Muenster: Lit Verlag, 2010) p.50.

70. Interview with Kikuyu youth, Kosovo, Mathare, 12 April 2010.

71. Interview with Kikuyu youth, Kobiro, Kawangware, 1 March 2010.

72. Interview with Luhya youth, Gatina, Kawangware, 10 April 2010.

73. Interview with Kalenjin youth, Kaptembwa, Nakuru, 20 June 2010.

74. Interview with Kisii youth, Satellite, Kawangware, 21 March 2010.

75. Interview with Kikuyu youth, Huruma, Eldoret, 3 February 2010. Cited in part in Jenkins (note 3) pp.587-8.

76. Jenkins (note 3) pp.588 -9.

77. Interview with Luo youth, Shabab, Nakuru, 3 June 2010.

78. Interview with Kikuyu youth, Kianda, Kibera, 11 November 2009. Cited in Jenkins (note 3) p.589.

79. Interview with elderly Kikuyu man, Huruma Eldoret, 25 January 2010.

80. Interview with Luhya youth, Kianda, Kibera, 20 November 2009.

81. Interview with Luo youth, Shabab, Nakuru, 3 June 2010.

82. Interview with Kamba youth, Ronda, Nakuru, 7 June 2010.

83. Interview with Luo youth, Nigeria, Mathare, 18 May 2010.

84. Ibid.

85. Interview with Borana youth, Kenya Service, Eldoret, 12 February 2010.

86. Interview with young Kikuyu woman, Nigeria, Mathare, 15 May 2010.

87. Interview with Luhya youth, Munyaka, Eldoret, 18 February 2010. 
88. Interview with young Kikuyu woman, Huruma, Eldoret, 28 January 2010.

89. Interview with Kikuyu youth, Kosovo, Mathare, 12 April 2010.

90. Ibid.

91. Interview with Kikuyu youth, Waithaka, 11 March 2010.

92. Interview with Luhya youth, Langas, Eldoret, 14 January 2010.

93. Marianne Gullestad, 'Invisible Fences: Egalitarianism, Nationalism and Racism', Journal of the Royal Anthropological Institute 8/1 (2002) p.54. 